\title{
A Rare Cause of Fatal Myocardial Infarction
}

Rohit Shriwastav, Dhiraj Kumar*, Sunny Shinde, Girish Sabnis, Dheeraj More, Pradeep Vaideeswar, Hetan C Shah, Charan Lanjewar and Prafulla Kerkar

Department of Cardiology, Seth GS Medical College and KEM Hospital, India

Submission: February 19, 2018; Published: March 20, 2018

*Corresponding author: Dhiraj Kumar, Department of Cardiology, Seth GS Medical College and KEM Hospital, Acharya Dhonde Marg, Parel, Mumbai, 400012, India, Tel: +91-9323361116; Email: dhiraj1645@gmail.com

Keywords: Arteritis; Takayasu; Coronary aneurysm; Massive myocardial infarctionion

\section{Case Report}

A 25-year-old male without any conventional coronary artery disease risk factors and history of untreated acute coronary syndrome a year back presented with rest angina and cardiogenic shock. On physical examination, her peripheral pulses though feeble, were palpable and there was no vascular bruit. There was an auscultable S3 and echocardiography suggested acute inferior wall and remote anterior wall myocardial infarction. (ECG Panel A) Despite attempts at resuscitation, the patient soon succumbed to refractory ventricular fibrillation. An autopsy was requisitioned. Gross examination of the heart at autopsy revealed humongous dilated, thrombus-laden coronary arteries (panel B, C, D). Histo-pathological examination with haematoxylineosin staining showed features of pointing towards a diagnosis of healing aortoarteritis with coronary involvement. Another remarkable observation was similar affection of the infra-renal aorta and right internal iliac artery- an exceedingly rare finding in Takayasu disease (panel E) (Figure 1).

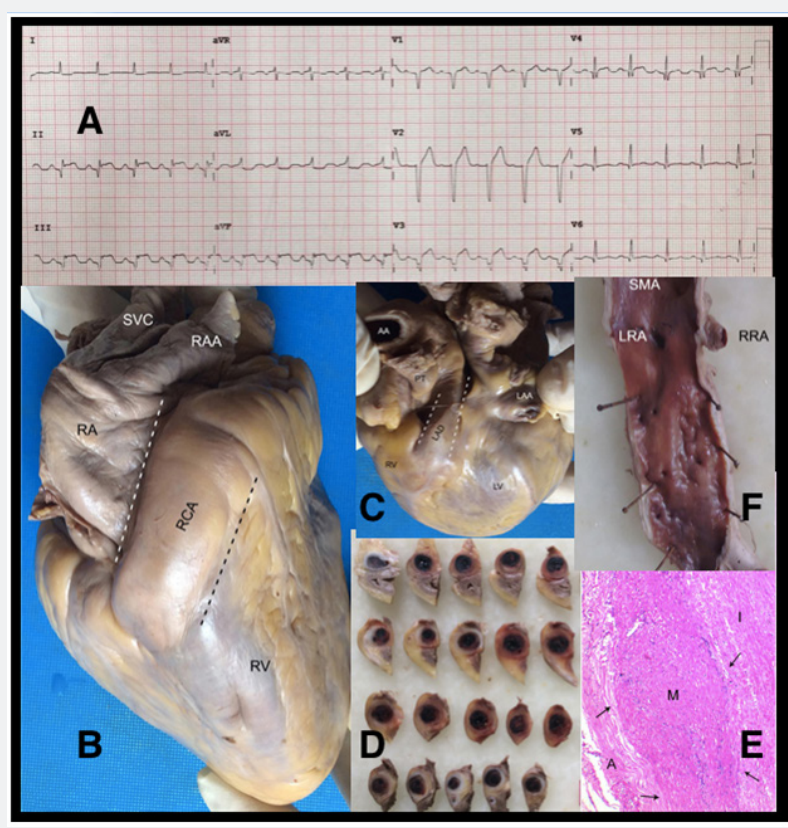

Figure 1: A. External aspect of the heart showing diffuse aneurismal dilatation of B. the right coronary artery RCA and C. left main and proximal left descending LAD coronary arteries (AA ascending aorta, LAA left atrial appendage, LV left ventricle, PT pulmonary trunk, Right atrium RA, RAA right atrial appendage, RV right ventricle, SVC superior vena cava) Figure 03: D. Serial cross-sections of the RCA (upper two rows) and LAD (lower two rows) showing luminal dilatation and thrombosis with grey-white thickening of their walls; E. Histology showed marked intimal thickening with destruction of the media $\mathrm{M}$ with focal inflammation and adventitial $\mathrm{A}$ fibrosis. 
Takayasu arteritis is common in Asian and Indian subcontinent [1]. An enigma since it was first described one century ago. It is "an idiopathic inflammatory disease of the large elastic arteries occurring in the young and resulting in occlusive or ectatic changes mainly in the aorta and its immediate branches as well as the pulmonary artery and its branches" [2]. About 8-12 percent patients can have significant affection of coronaries as well [3]. Although affects young females generally below age of 40 although males can also be affected. This case highlights the causal role of aorto-arteritis with subsequent coronary aneurysm formation and thrombosis as an often-missed aetiology of myocardial infarction. The histopathological features have been described very well by Kinare et al. [4]. Any young patient with no conventional risk factors should have their peripheral pulses examined in order not to miss this important treatable cause.

\section{References}

1. Sen PK, Kinare SG, Kelkar MD, Nanivadekar SA (1972) Nonspecific stenosing arteritis of the aorta and its branches: a study of possible etiology. Mt Sinai J Med 39(3): 221-242.

2. Bahl VK, Seth S (2002) Takayasu arteritis revisited. Indian Heart Journal 54: 147-151.

3. Panja M, Sarkar C, Kar AK, Kumar S, Mazumder B, et al. (1998) Coronary artery lesions in Takayasu arteritis--clinical and angiographic study. J Assoc Physicians India 46(8): 678-681.

4. Kinare S, Gandhi MS, Deshpande JR (1998) Non-specific aorto-arteritispathology and radiology. ( $1^{\text {st }}$ edn), Quest Publications, Greece.

\section{Your next submission with Juniper Publishers} will reach you the below assets

- Quality Editorial service

- Swift Peer Review

- Reprints availability

- E-prints Service

- Manuscript Podcast for convenient understanding

- Global attainment for your research

- Manuscript accessibility in different formats ( Pdf, E-pub, Full Text, Audio)

- Unceasing customer service

Track the below URL for one-step submission https://juniperpublishers.com/online-submission.php 